\title{
Kansalaisopistoja todella tarvitaan
}

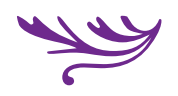

VAPAA SIVISTYSTYÖ vai valtion sivistystyö - peräänkuulutammeko me vapaudella itsemääräämisoikeutta vai vapautta tavoitteista ja tutkinnoista, vapaata koulutusta? Voimmeko edes tavoitella itsemääräämisoikeutta tilanteessa, jossa toimintaamme säätelevät lait ja asetukset ja eurot siihen tulevat valtiolta, kunnilta ja kansalaisilta?

Tehtävänämme on vastata paikalliseen ja alueelliseen sivistystarpeeseen. Kansalaisopisto ei elä valtiona valtiossa, vaan se on osa ympäröivää todellisuutta ja toimii yhteistyössä yhteisönsä kanssa.

Puhumme elämänlaajuisen oppimisen puolesta, mutta usein asialla tarkoitetaan vain tutkintoon johtavaa koulutusta. Kaikki koulutus tukee elinikäistä oppimista, myös vapaa sivistystyö ja kansalaisopisto.

\section{ETSITÄÄN VAPAAN SIVISTYSTYÖN PUOLUSTAJIA}

Päättäjät ja valtion virkaihmiset hehkuttavat suomalaisten osaamis- ja sivistystasoa, PISA-tuloksia, yliopistouudistusta ja yhteiskuntatakuuta. Vain harvoin muistetaan mainita vapaa sivistystyö, kun puhutaan oppimisesta, osaamisesta, sivistyksestä tai elinikäisestä oppimisesta.

Valtion hallinnosta vapaan sivistystyön puolestapuhujia ei tahdo löytyä hakemallakaan. Vapaa sivistystyö saattaa tulla mieleen, jos päättäjällä on omakohtaista kokemusta jostakin sen oppilaitosmuodosta.

Ihmettelen tarttumapinnan puutetta - onhan jokainen päättäjä jostain kotoisin, ja jokaisessa Suomen kunnassa on kansalaisopiston toimintaa! Eikö ole trendikästä puolustaa kansalaispiston resursseja vai iskeekö miljoonasokeus asioista päätettäessä?

Kaikilla koulutusmuodoilla on omat uudistamisja kehittämisohjelmansa väyläämässä tietä tulevaisuuteen. Myös kansalaisopistotoiminnan tulevaisuu- den suunnittelu ja toimialan jatkuva kehittäminen edellyttävät uutta vapaan sivistystyön kehittämisohjelmaa. On muistettava, että myös valtion tulevaisuustutkimukseen käytettiin sievoinen summa.

\section{KANSALAISOPISTO KOHTI TULEVAISUUTTA}

Kansalaisopistoilla menee hyvin, jos tarkastelemme opistojen vuotuisia käyttäjämääriä: 640000 nettoopiskelijaa ja 1,1 miljoonaa brutto-osallistujaa. Tavoitamme hyvin tiettyjä ryhmiä, mutta opistotyön haasteena on turvata tulevaisuudessa kaikkien kansalaisten tasa-arvoiset oppimismahdollisuudet.

Kansalaisopistot ovat myös miesten, pienipalkkaisten, kouluttamattomien, erityisryhmien, maahanmuuttajien, työttömien, työelämään palaavien vanhempien ja ikääntyvien opinahjoja. Oppiva ihminen elää täyttä elämää, sillä vierivä kivi ei sammaloidu eikä syrjäydy.

Tutkimustulosten mukaan tiedämme, että kulttuuriharrastus pidentää ikää ja lisää terveyttä ja hyvinvointia. Tietoa on syytä hyödyntää Suomi Oy:n kehittämisessä ja kansalaisten elinvoiman turvaamisessa. On suorastaan paradoksaalista, että emme ole köyhiä emmekä kipeitä, kun etsitään rahaa pahoinvoinnin seurausten jälkisammutukseen. Kallista taas on, kun rahaa tarvitaan ennaltaehkäisevään toimintaan.

\section{TAITEEN PERUSOPETUSTA KAIKILLE}

Pitkässä juoksussa ennaltaehkäisy on aina halvempaa kuin huostaanotot, mielenterveyden häiriöiden tai päihdeongelmien hoito. Milloin oikein ymmärrämme ennaltaehkäisevän toiminnan merkityksen ja ihmisen kasvun tukemisen kulttuurin keinoin?

Nykyisin puhumme yhteiskunta- ja nuorisotakuusta. Suomen kannattaa satsata lasten ja nuorten 
tulevaisuuteen taiteen perusopetusta lisäämällä ja laajentamalla. Yhteiskuntatakuun resursseilla on syytä kehittää taideseteli nuorten osallistumiskynnyksen madaltamiseksi. Kulttuuri-, taito- ja taideaineet kuuluvat olennaisesti sivistykseen ja sivistysvaltioon.

Taiteen opetus tukee yksilöiden kasvua ja kehittymistä. Se vahvistaa paitsi lasten ja nuorten sosiaalistumista ja integroitumista yhteiskuntaan myös tukee aikuisten työkykyä ja hyvinvointia. Aikuisille taiteen perusopetuksen laaja oppimäärä tarjoaa mitä parhaimman väylän ammatissa erikoistumiseen tai ammatinvaihtoon. Taiteen perusopetus tulee turvata tasapuolisesti koko Suomessa.

\section{KANSALAISOPISTOTOIMINTA VIENTITUOTTEEKSI}

Suuri osa kansalaisopistoista on kuntien ylläpitämiä. Yksityiset setlementtiopistot jatkavat kansalaisopistotoiminnan lisäksi yhteiskunnallisesti merkittävää monialaista tuki- ja auttamistyötä ihmisten elämänkulun eri vaiheissa. Työlle on tilausta myös tulevaisuudessa.

Kansalaisopisto-osaamista sopii jalostaa vetovoimaiseksi vientituotteeksi EU-rahoituksella esimerkiksi tukemaan naisten asemaa koulutuksen avulla. Ulkomaiset opetusviranomaiset käyvät tutustumassa Suomen koulutusjärjestelmään ja hämmästelevät perusopetuksen oppimistuloksia. On jo aika esitellä heille myös suomalaista kustannustehokasta kansalaisopistotoimintaa, josta voimme olla ylpeitä ja josta koko maailma voi ottaa mallia vaikuttavuutensa perusteella.

Voimme mitata toimintamme onnistumista monilla asioilla, ja tulevaisuutemme on täynnä niin mah- dollisuuksia kuin myös uhkia. Mahdollisuuksiin tarttuminen edellyttää resursseja.

\section{RAHAA, RAHAA, RAHAA}

Kansalaisopistojen liiton hallitus on linjannut rahoitukseen liittyviä tavoitteitaan, joita ovat: kansalaisopistoja koskevan rahoituslain avaaminen ja yhteen yksikköhintaan siirtyminen, rahoituksen turvaaminen, opistosetelirahan lisääminen ja jo mainitun taiteen perusopetusseteleiden kehittäminen.

Kansalaisopiston tulot koostuvat pääasiassa valtionosuudesta, kunnan maksuosuudesta ja kurssimaksutuloista. Kolmikantarahoitus muodostaa varsinaisen triangelidraaman, sillä muutos jossakin osassa vaatii tasapainotusta toisessa, tai muuten kokonaisuus kärsii.

Valtionosuuden saaminen on melkoista oravanpyörässä juoksemista: mitä enemmän opisto saa pelimerkkejä ylläpitäältä tai opiskelijoilta, sitä enemmän se pystyy toteuttamaan opetustunteja ja saa enemmän valtionosuutta.

Tuntikilpajuoksussa nopeat syövät hitaat, eli ne opistot, joilla menee hyvin, pärjäävät entistä paremmin. Nykyinen kansalaisopistojen valtionosuuden jakosysteemi valitettavasti heikentää alueellista koulutuksellista tasa-arvoa. Kansalaisopiston toiminnan turvaaminen, kehittäminen ja uusien kohderyhmien tavoittaminen vaativat vakautta rahoitukseen ja turvaa toimeentuloon.

\section{KUNNILLE MALTTIA}

Taloudellisten resurssien näkökulmasta kansalaisopistoilla menee huonosti. Viime vuosina vapaa sivistystyö ja kansalaisopistotoiminta ovat jääneet resurssien jaossa lapsipuolen asemaan. 


\title{
MiLloin OIKEIN
}

\author{
YMM ̈̈RRÄMME \\ ENNALTAEHK ̈̈ISEVÄN
}

TOIMINNAN

MERKITYKSEN?

Kansalaisopistojen valtionosuutta on leikattu voimakkaasti ja sen seurauksena niissä on menossa kurjistumisen kierre. Opistojen valtionosuus on jämähtänyt vuoden 2010 tasolle. Voimme kysyä, onko vapaan sivistystyön aika ohi, kun valtiovalta jäädyttää indeksikorotukset ja supistaa vapaan sivistystyön rahoitusta vuodesta toiseen?

Kurjistumista lisää kansalaisopistonsa toimintaa tukevien kuntien heikko taloustilanne. Myös yksityisten ylläpitäjien rahoituspohja on kaventunut, kun kunnat vähentävät avustuksiaan opistoille tai eivät maksa niitä lainkaan. On tärkeää, että kunnat eivät tee tässä murroksessa hätiköityjä ratkaisuja. Kansalaisopistotoimintaa ei saa nähdä pelkästään kulueränä.

Esimerkiksi 90-luvun laman aikaan kunnat lakkauttivat vakinaisten opettajien virkoja opistoista, eikä niitä ole takaisin saatu.

\section{HYVINVOINTIIN KANNATTAA PANOSTAA}

Kansalaisopistojen liitto KoL teki keväällä jäsenopistojensa rehtoreille kyselyn. Selvisi, että kustannussäästönä lähes kaikissa opistoissa on nostettu kurssimaksuja tai ryhmien minimiopiskelijamäärää. On selvää, että kohonneita kustannuksia ei voi kattaa kurssimaksuja nostamalla. Vastaajat olivat huolissaan siitä, että korotukset koskettavat eniten henkilöitä, jotka erityisesti tarvitsevat vapaan sivistystyön palveluja.

Kurssimaksu ei saa olla osallistumisen este - tavoitteena tulee edelleen olla tasa-arvoisten oppimisja osallistumismahdollisuuksien turvaaminen kaikille ja kaikkialla.

KoLin tavoitteena on pitkään ollut yhteen yksikköhintaan siirtyminen, sillä tutkimustulokset eivät tue valtionosuuden kaksihintajärjestelmää. Kansalaisopistojen yksikköhintaa porrastetaan nykyisin niin, että se on viisi prosenttia muiden hintaa korkeampi opistossa, jonka sijaintikunnan asukastiheys on yli 100.

Menot eivät todellakaan ole riippuvaisia siitä, kuinka tiheässä opiston alueella asuu asukkaita. Kaksihintajärjestelmä ei tue sivistyksellistä tasa-arvoa, vaan päinvastoin. KoLin laskelmien mukaan yhteen yksikköhintaan siirtyminen maksaa vaihtoehdosta riippuen 8-9 miljoonaa. Rahoitusuudistuksessa on nostettava myös yksityisten kansalaisopistojen ylläpitäjien yksikköhintaa arvonlisäveron verran, koska yksityiset opistot eivät voi vähentää arvonlisäveroja.

Kallistako? Ei todellakaan. Tässä taloudellisessa tilanteessa yhteisöllisyyden tukemiseen, aktiiviseen kansalaisuuteen ja hyvinvointiin pitää olla varaa satsata.

Hallitusohjelman mukaan menestyvä Suomi perustuu kannustavuuden, sivistyksen, suvaitsevaisuuden ja välittämisen arvoille. Ohjelma korostaa sivistyksen ja osaamisenmerkitystä sekä tasa-arvoisia koulutusmahdollisuuksia.

Unelma sivistyneestä maasta elää!

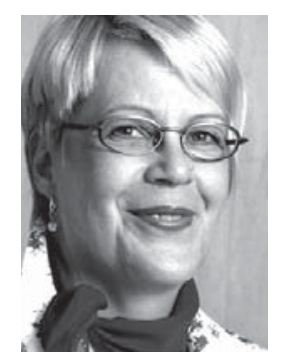

Liisa Vornanen Jokihelmen opiston rehtori Kansalaisopistojen liiton (KoL) hallituksen puheenjohtaja 